\title{
Synthesis and characterization of boron nitride nanotubes (BNNTs) with a new method and precursor materials
}

\author{
Yeni bir yöntem ve öncü maddeler ile bor nitrür nanotüplerin (BNNT'lerin) sentezi ve \\ karakterizasyonu
}

Tuba TARHAN ${ }^{* 1, a}$

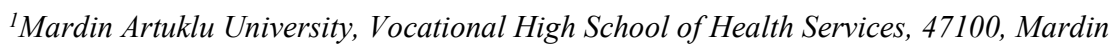

\begin{abstract}
Boron nitride nanotubes (BNNTs) have many application areas thanks to their superior properties such as thermal and electrical insulation, resistance to oxidation, high hydrophobicity, and high hydrogen storage capacity, as well as biocompatible properties. Therefore, new synthesis methods are being searched for BNNT with increasing interest in recent years. In this study, high purity and yield BNNTs were synthesized using precursor materials and methods that were not previously tried in the literature. A chemical vapor storage (CVD) furnace was used for the synthesis, and various parameters were changed to achieve optimum conditions. The structure of the obtained BNNTs was characterized by Fourier conversion infrared spectroscopy (FTIR), Raman spectroscopy, and a UV-visible spectrophotometer. In addition, surface morphologies were illuminated using transmission electron microscopy (TEM) and scanning electron microscopy (SEM). However, it has been observed that BNNTs obtained as a result of HR-TEM (high-resolution transmission electron microscope) analysis have a single-walled structure that is difficult to synthesize. This increases the importance and quality of synthesized BNNTs.
\end{abstract}

Keywords: BNNTs, Characterization, Synthesis

$\ddot{O} z$

Bor nitrür nanotüpler (BNNT'ler) ısıl ve elektriksel yalıtkanlıklarl, oksidasyona karşı dayanıklllıkları, yüksek hidrofobiteleri ve yüksek hidrojen depolama kapasiteleri gibi üstün özelliklerinin yan sıra biyouyumlu özellikleri sayesinde birçok uygulama alanına sahiptir. Dolaylsılyla BNNT için son yllarda gittikçe artan bir ilgiyle yeni sentez yöntemleri araştırlmaktadır. Bu çallş̧mada, literatürde daha önce denenmemiş öncü maddeler ve yöntemle yüksek saflkta ve verimde BNNT'ler sentezledi. Sentez için bir kimyasal buhar depolama (CVD) firını kullanıldı ve çeşitli parametreler değiştirilerek optimum koşullar elde edildi. Elde edilen BNNT'lerin yapısı fourier dönüşümlü kizılötesi spektroskopisi (FTIR), Raman spektroskopisi ve bir UV-visible spektrofotometresi kullanilarak karakterize edildi. Ayrica yüzey morfolojileri geçirimli elektron mikroskobu (TEM) ve taramal elektron mikroskobu (SEM) kullanilarak aydınlatıldl. Bunla birlikte HR-TEM (yüksek çözünürlüklü geçirimli elektron mikroskobu) analiz sonuçlarına göre elde edilen BNNT'lerin, sentezlenmesi zor olan tek duvarlı (single-walled) bir yapıya sahip olduğu görülmüştür. Buda sentezlenen BNNT'lerin önemini ve kalitesini artturmaktadır.

Anahtar kelimeler: BNNT'ler, Karakterizasyon, Sentez

\footnotetext{
${ }^{*}$ a Tuba TARHAN; tubatarhan@artuklu.edu.tr; Tel: +90 482213 4002-7285; orcid.org/0000-0003-2656-4464
} 


\section{Introduction}

Structurally, BNNTs are an analog of Carbon nanotubes (CNTs) (Iijima, 1991). BNNTs containing boron and nitrogen atoms evenly distributed in hexagonal rings have attracted great attention due to their excellent mechanical properties, high thermal conductivity, antioxidation stability, excellent biocompatibility, and effective light-emitting properties (Chang et al., 2005; Lauret et al., 2005; Berber et al., 200; Gao et al., 2011). These properties have made BNNTs great materials. In addition, due to their biocompatible properties, they have a wide range of applications in medicine and biomedical applications. A few of the application areas of BNNTs are; they can chemically bind to carbohydrates, DNA molecules, and proteins (Zhi et al., 2007; Chen et al., 2009; Gao et al., 2012). By adding to various polymers used in tissue engineering studies, increases the physical strength of the tissue scaffold and supports its proliferation by facilitating cell attachment to the scaffold (Salvetti et al., 2015). It can be modified to oligonucleotides in gene silencing studies (Şen et al., 2017). It can be used as a drug carrier (Ciofani et al., 2009, 2010), and as photoelectric and neutron radiation shield materials in semiconductor devices and thermal conductive composites under high temperatures (Fu et al., 2017; Chang et al., 2006; Bai et al., 2007; Cao et al., 2009).

Ferreira et al. reported a facile and effective synthesis based on chemical vapor deposition (CVD) process with new conditions to produce boron nitride nanotubes in higher amount. They used boron powder, ammonium nitrate, and hematite as catalysts in tubular furnace, and also they without used extreme conditions for synthesis BNNTs (Ferreira et al., 2011). Nithya et al. successfully synthesized BNNT by a simple annealing process. They used amorphous boron powder (B) as a boron source to react with various metal oxide mixtures $\left(\mathrm{V}_{2} \mathrm{O}_{5} / \mathrm{Fe}_{2} \mathrm{O}_{3}\right.$ and $\mathrm{V}_{2} \mathrm{O}_{5} / \mathrm{Ni}_{2} \mathrm{O}_{3}$ ) in their study (Nithya et al., 2014). Wu et al. high purity and large quantities of BNNTs have been successfully synthesized under ammonia gas flow at $1200{ }^{\circ} \mathrm{C}$.

They used boric acid, ethylenediamine, and Iron (III) nitrate nonahydrate as the raw materials. They synthesized via a wet chemistry method and used as catalytic pyrolysis of organic-inorganic hybrid precursor. They were observed that the diameter of BNNTs was distributed in a range of 60-200 nm while its length was about tens of microns (Wu et al., 2017). Wang et al. via a novel two-step method, including citrate-nitrate combustion reaction and catalytic chemical vapor deposition high-quality boron nitride nanotubes successfully synthesized. The obtaining nanotubes the diameter ranges between 20 and $80 \mathrm{~nm}$, while the length is about dozens of micrometers (Wang et al., 2018). Kumar et al. synthesized 1D and 2D nanostructures and applied them for bioimaging of breast cancer cells (MCF-7). They grew nanotubes on a tungsten substrate by using copper as a catalyst with a simple and easy method. They carried out using solid precursor, boric oxide, and urea for boron and nitrogen, in a high-temperature furnace under argon atmosphere. The obtaining product was characterized by FESEM, TEM, FTIR (Kumar et al., 2018). Tang et al. with a mixture of $\mathrm{B}_{2} \mathrm{O}_{2}$ and $\mathrm{Mg}$, a novel precursor, successfully synthesized bulk amounts of pure $\mathrm{BN}$ nanotubes at $1300{ }^{\circ} \mathrm{C}$. After the reaction, $\mathrm{Mg}$ was evaporated from the final product (Tang et al., 2002). Pakdel et al. BNNT films, via a catalytic chemical vapor deposition (CVD) method on silicon/silicon dioxide $(\mathrm{Si} / \mathrm{SiO} 2)$ substrates in a horizontal electric furnace synthesized. Furthermore, the effects of growth temperature and catalyst concentration on the morphology of the films were investigated in the study. The BNNT films were grown at 1200 and $1300{ }^{\circ} \mathrm{C}$ average outer diameters were measured as $\sim 30$ and $\sim 60 \mathrm{~nm}$, respectively. On the other hand, the BNNT films were grown at $1400{ }^{\circ} \mathrm{C}$ average diameters of thick tubes $\sim 100 \mathrm{~nm}$, and thin ones as $\sim 10 \mathrm{~nm}$ were measured (Pakdel et al., 2012). Lee et al. for the first time, at $1200{ }^{\circ} \mathrm{C}$, using $\mathrm{MgO}, \mathrm{Ni}$, or $\mathrm{Fe}$ as the catalysts, and an $\mathrm{Al}_{2} \mathrm{O}_{3}$ diffusion barrier as an underlayer, through a catalytic chemical vapor deposition (CVD) method synthesized BNNTs. Obtained BNNTs were clean, vertically aligned, and have high crystallinity (Lee et al., 2010).

Turkey is a country rich in groundwater resources, which ranks first in the world in terms of boron reserves, the US, China, Russia, Kazakhstan, and South America come after Turkey (Eti Maden for life, 2021). The most important known uses of boron compounds are; It is used in automotive, detergent and agriculture industry, chemical industry, glass, fuel cells, space and aircraft, and ceramic materials (Eti Maden for life, 2021). It is of great importance to developing new, economical, and high value-added boron usage areas for boron minerals, which have an important place for our country. Synthesizing BNNTs, which are obtained from boron minerals and which importance and usage areas it has been mentioned above, as pure, in large quantities, and 
economically as possible have special importance in this sense.

In this study, the synthesis method performed with precursor materials used in BNNT synthesis has not been tried in the literature before. As far as we know, $\mathrm{Fe}_{2} \mathrm{O}_{3}$ nanoparticles as a catalyst for these precursor materials were first used in this study. Moreover, the temperature parameters and time applied in the study were first optimized for this study. Synthesized BNNTs with these starting materials are highly pure by this method and there is no need to apply a long washing procedure with concentrated strong acids (Generally, washing processes in the synthesis of BNNTs are carried out with $4 \mathrm{M} \mathrm{HCl}$ and $1 \mathrm{M} \mathrm{HNO}_{3}$, a procedure that takes hours). After reaction obtaining product was dispersed in hot water $\left(85^{\circ} \mathrm{C}\right)$ and followed by filtrated. This situation increases the importance of the study. Because it is believed that washing with concentrated acid for a long time deformed the morphology of BNNTs and reduced the quality of the product. A chemical vapor storage (CVD) furnace was used for the synthesis and carried out in high purity and yield by determining the optimum conditions required. BNNTs obtained after synthesis were characterized by FTIR, Raman, UV-visible spectrophotometer. In addition, it was observed the BNNTs which surface morphologies were illuminated by using TEM and SEM have a single-walled structure.

\section{Material and method}

First, $300 \mathrm{mg}$ of Boron trioxide $\left(\mathrm{B}_{2} \mathrm{O}_{3}\right), 300 \mathrm{mg}$ of urea $\left(\mathrm{C}_{3} \mathrm{H}_{8} \mathrm{O}_{2}\right)$, and as a catalyst $30 \mathrm{mg}$ of iron (III) oxide nanoparticles $\left(\mathrm{Fe}_{2} \mathrm{O}_{3}\right)$ were until well dispersed with the aid of a sonicator in $3 \mathrm{~mL}$ of 13.38M ammonia solution $\left(\mathrm{NH}_{3}\right)$ in a beaker. The obtaining mixture was well spread on the silicon carbide ( $\mathrm{SiC}$ ) plate (The size of the $\mathrm{SiC}$ plate is $2 \mathrm{x}$ $3 \mathrm{~cm}$ ) with the aid of a spatula and heated on a heater at $120^{\circ} \mathrm{C}$ until the solvent evaporated. Afterward, it was heated in a chemical vapor storage (CVD) furnace on the plate until to $1300{ }^{\circ} \mathrm{C}$ for about 120 minutes $\left(10{ }^{\circ} \mathrm{C} / \mathrm{min}\right)$ in an atmosphere of $\mathrm{NH}_{3}$ gas. $\mathrm{NH}_{3}$ gas flow rate was kept constant at 100-200 $\mathrm{sccm}$ during the reaction. Then, heating was continued at $1300{ }^{\circ} \mathrm{C}$ for 180 minutes and the furnace was turned off and the temperature was allowed to drop to $550{ }^{\circ} \mathrm{C}$ (this process took about 120 minutes). The reaction was terminated at $550{ }^{\circ} \mathrm{C}$ and the $\mathrm{SiC}$ plate was removed from the furnace and allowed to cool at room temperature. After reaction obtaining product was dispersed in hot water $\left(85^{\circ} \mathrm{C}\right)$ and followed by filtrated. Thus, if unreacted boron trioxide and urea remain, they are dissolved in water and separated from the obtained product. The reaction formation steps were schematized in Figure 1.
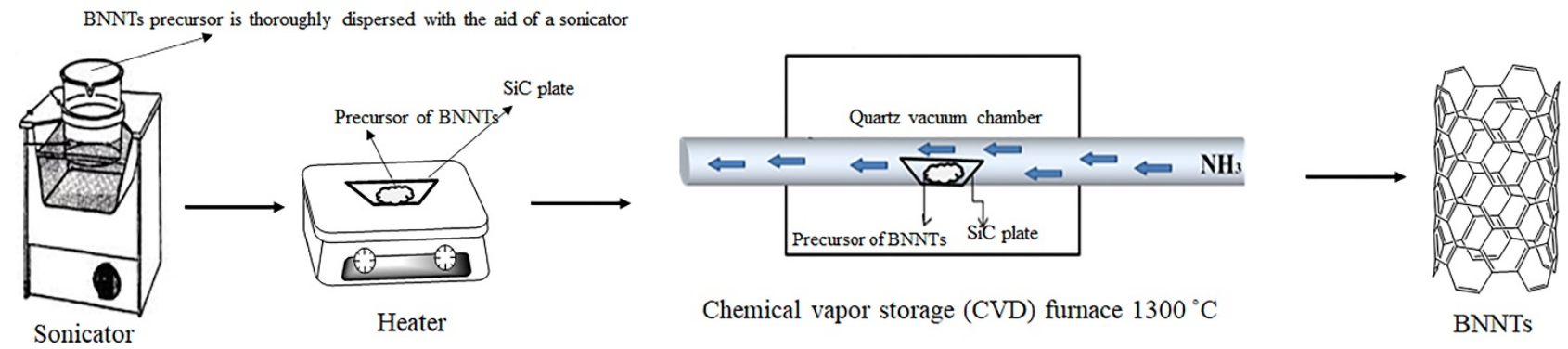

Figure 1. Scheme of the method

\subsection{Chemicals}

Boron trioxide $\left(\mathrm{B}_{2} \mathrm{O}_{3}\right)$ urea $\left(\mathrm{C}_{3} \mathrm{H}_{8} \mathrm{O}_{2}\right)$, and iron (III) oxide nanoparticles $\left(\mathrm{Fe}_{2} \mathrm{O}_{3}\right)$ were obtained from Sigma Aldrich. Ammonium Hydroxide $\left(\mathrm{NH}_{3}\right)$ was purchased from BDH Chemicals.

\subsection{Instruments}

A chemical vapor storage (CVD) furnace (Protherm PTF 14/50/450) was used for the synthesis. Synthesized BNNTs were characterized using FTIR (FTIR, Thermo NICOLET IS50 spectrometer; Thermo Fisher Scientific Inc.,
Waltham, MA, USA), Raman (Renishaw inVia reflex; Renishaw plc, Gloucestershire, UK), and UV / Vis (PerkinElmer Lamda 25; PerkinElmer, Inc., Waltham, MA, USA) spectrophotometers. And also, SEM (Carl Zeiss EVO 40; Carl Zeiss Microscopy GmbH, Oberkochen, Germany) and TEM (FEI TALOS F200S 200 kV; Thermo Fisher Scientific Inc.) microscopes were used to illuminate surface morphology. All characterization procedures were performed under laboratory conditions. Also, no action was taken on the samples before analysis. 


\section{Result and discussion}

\subsection{Characterization studies}

Synthesized BNNTs were first characterized by FTIR. As shown in Figure 2, the characteristic B$\mathrm{N}-\mathrm{B}$ and $\mathrm{B}-\mathrm{N}$ vibration bands were observed at $1348 \mathrm{~cm}^{-1}$ at $764 \mathrm{~cm}^{-1}$, respectively (Kalay et al., 2013). The broad absorption band at $1348 \mathrm{~cm}^{-1}$ is attributed to the $\mathrm{E}_{1}{ }_{u}$ (B-N stretching vibration mode perpendicular to the c-axis) modes of h-BN; while the absorption band of the weaker peak at $764 \mathrm{~cm}^{-1}$ could be associated with the $\mathrm{A}_{2 u}$ (B-N-B bending vibration mode parallel to the $\mathrm{c}$-axis) ( $\mathrm{Xu}$ et al., 2007; Wu et al., 2017). Furthermore, the FTIR result showed that BNNTs were successfully synthesized. It was not observed absorption band related to the raw materials, which suggests that the as-prepared BNNTs are relatively pure.

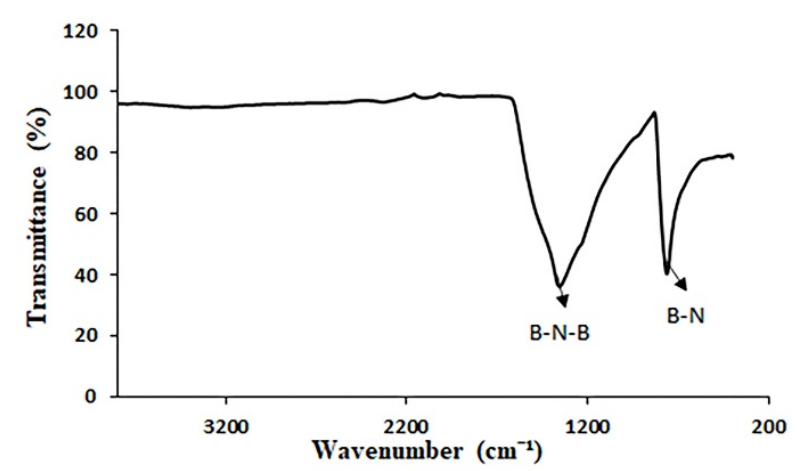

Figure 2. FTIR spectrum of the BNNTs

In Figure 3 was given the Raman spectrum for BNNTs. While preparing the BNNTs for Raman measurement, firstly, it was thoroughly dispersed in deionized water. In Raman measurements, liquid samples were analyzed by dropping onto a $\mathrm{CaF}_{2}$ slide. Previously, the $\mathrm{CaF}_{2}$ slide washed with ethanol and dried. $2.5 \mu \mathrm{L}$ of the BNNTs were dropped on the slide and left to dry in a closed environment. The measurement of the completely dried sample was taken using a diode laser at 830 $\mathrm{nm}$ that arranged to $10 \mathrm{sec}$ exposure time and a $50 \times$ objective (numerical aperture, 0.75 ) with a laser power of $50 \mathrm{~mW}$. According to the spectrum in Figure 3, characteristic peaks regarding $\mathrm{CaF}_{2}$ and BNNTs were observed at 322 and $1365 \mathrm{~cm}^{-1}$, respectively (Arenal et al., 2006). A sharp Raman peak at $\sim 1365 \mathrm{~cm}^{-1}$ corresponds to the in-plane vibrational Raman active $E_{2 g}$ mode of $h-B N$ (Nithya et al., 2014). In this mode, the B and $\mathrm{N}$ atoms were moving against each other within a plane. Lee et al. have also reported a similar observation for BNNTs (Lee et al., 2008). This result shows that the purified BNNTs were crystalline and free from impurities.

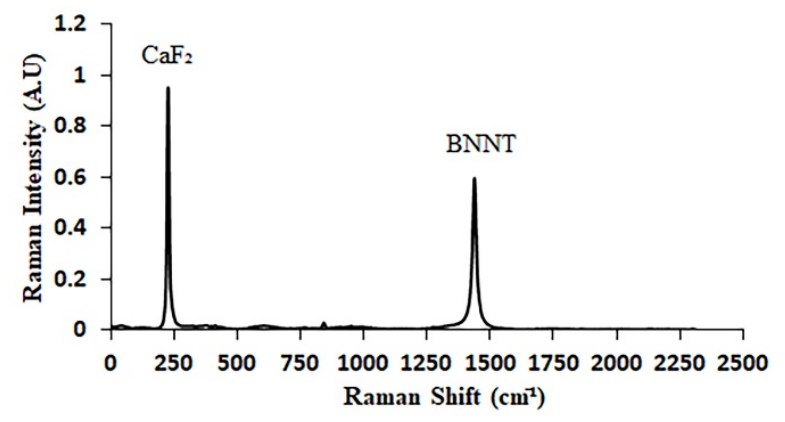

Figure 3. Raman spectrum of the BNNTs

Besides, the UV-vis. spectrophotometer was used to prove the presence BNTTs. Accordingly, a strong absorbance value at $214 \mathrm{~nm}$ in Figure 4 shows the characteristic absorbance peak for BNNTs. In addition, the results are accordance with the literature (Roy et al., 2014).

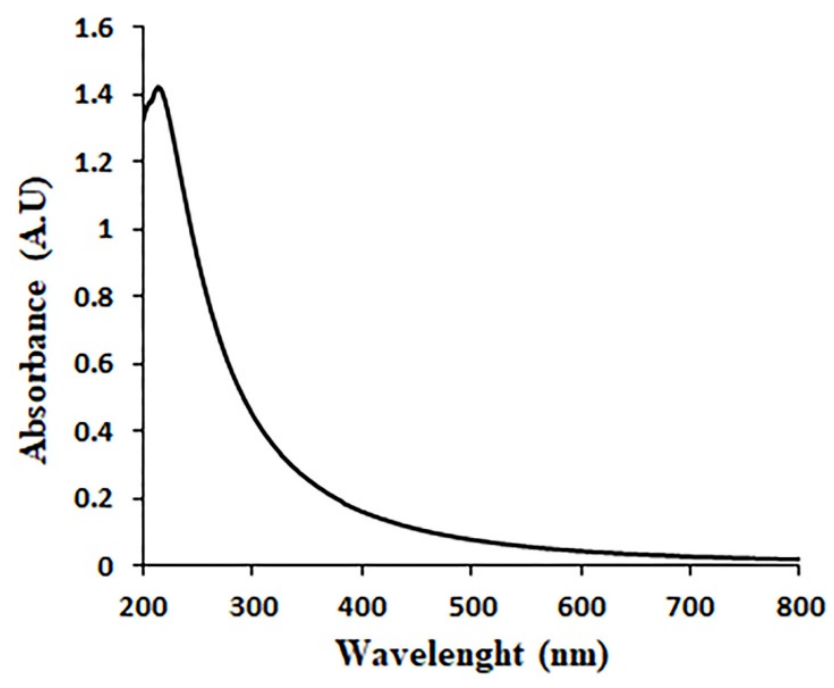

Figure 4. UV-vis. spectrum of the BNNTs 
SEM and TEM microscopes were used to view the BNNTs and their surface morphologies. In Figure 5 , it can be seen from the SEM image that BNNTs were clearly formed. As can be seen from this image, most of the precursor materials have turned into BNNTs. This indicates that the obtained BNNTs are of high purity. In addition, the results are in agreement with the FTIR spectrum.

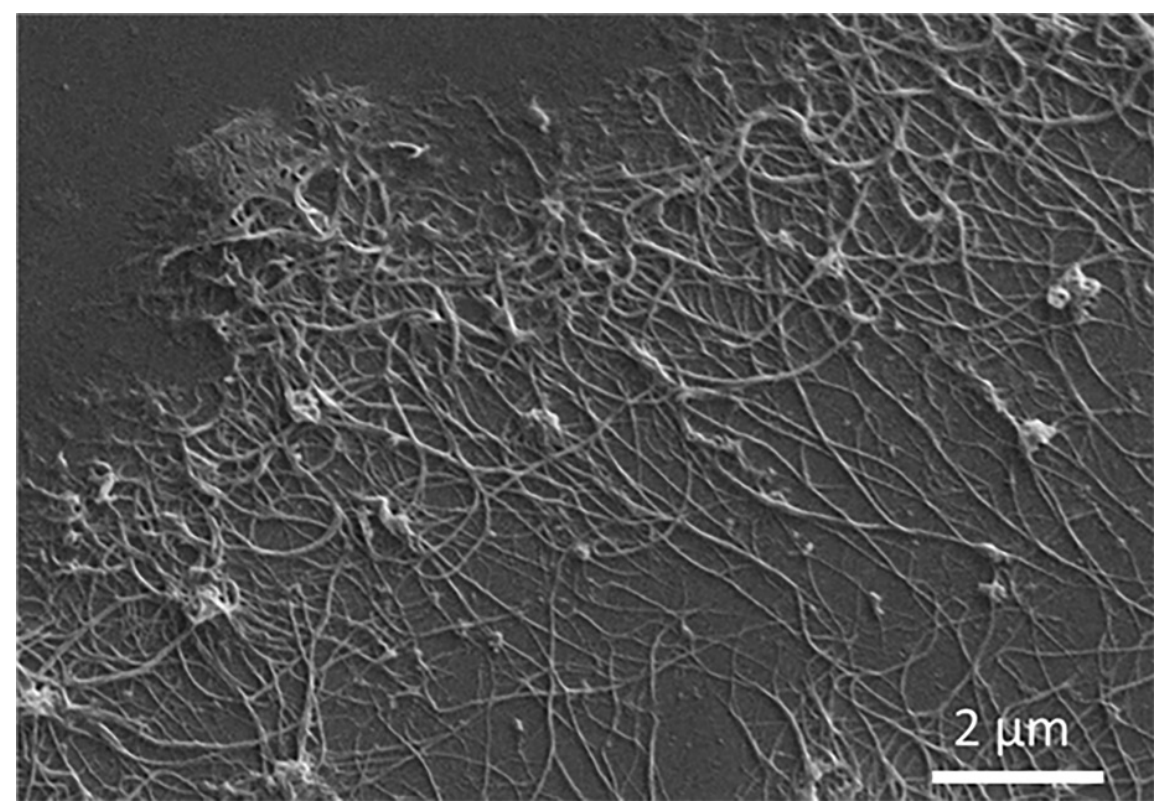

Figure 5. SEM image of the BNNTs

In addition to the SEM image, HR-TEM images at 200 and $50 \mathrm{~nm}$ scales were shown in Figure 6 to show that the BNNTs exhibited a single-walled

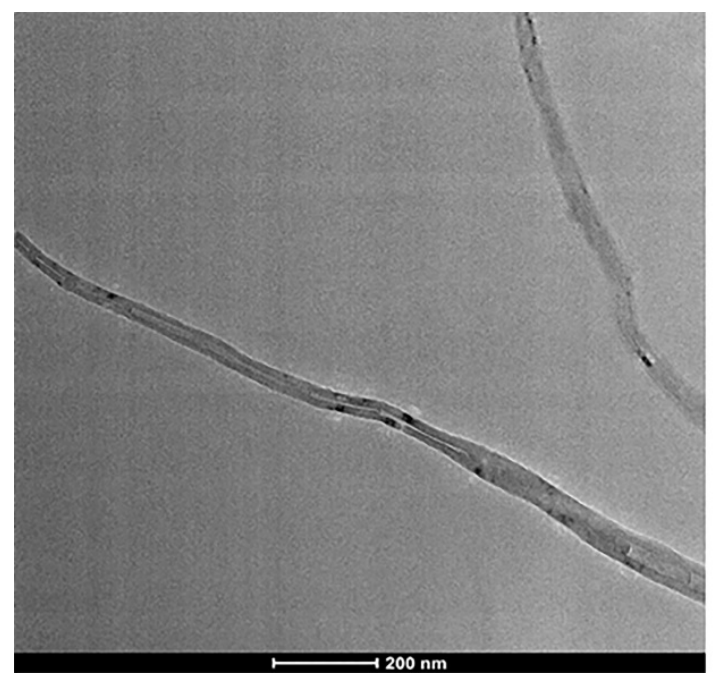

Figure 6. HR-TEM images of the BNNTs

Furthermore, Table 1 gives information on the average diameters of BNNTs obtained using different initial materials and catalysts. And also, the obtained results were compared with this study. The results showed that there is no similar synthesis method using the same initial materials and catalyst. structure. Moreover, it can be seen from these images that the surface of BNNTs was smooth, and their diameters were below $50 \mathrm{~nm}$.

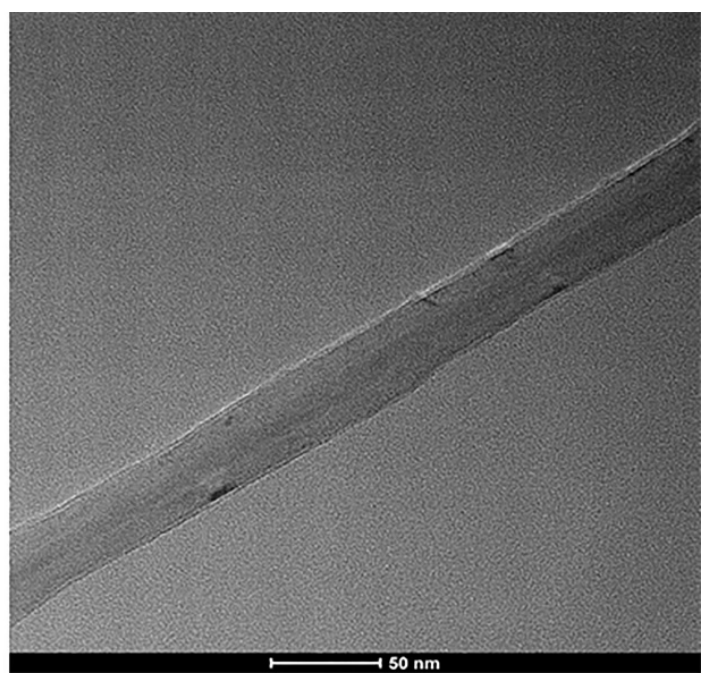


Table 1. Comparison of initial materials, catalyst, and the ranges of diameter BNNTs

\begin{tabular}{|c|c|c|c|}
\hline Initial materials & Catalyst & The ranges of diameter BNNTs & Reference \\
\hline $\begin{array}{l}\text { Boron powder and } \\
\text { ammonium nitrate }\end{array}$ & Hematite & About $100 \mathrm{~nm}$ & $\begin{array}{l}\text { Ferreira et } \\
\text { al., } 2011\end{array}$ \\
\hline $\begin{array}{l}\text { Amorphous boron } \\
\text { powder }\end{array}$ & $\begin{array}{l}\text { Metal oxide mixtures } \\
\left(\mathrm{V}_{2} \mathrm{O}_{5} / \mathrm{Fe}_{2} \mathrm{O}_{3} \text { and }\right. \\
\left.\mathrm{V}_{2} \mathrm{O}_{5} / \mathrm{Ni}_{2} \mathrm{O}_{3}\right)\end{array}$ & $\begin{array}{l}\text { The lengths of the tubes were found to be }>1 \mu \mathrm{m} \text {. } \\
\text { And also, The inner and outer diameters of the } \\
\text { tubes were found to be } 5.16 \text { and } 10.96 \mathrm{~nm} \text {, } \\
\text { respectively }\end{array}$ & $\begin{array}{l}\text { Nithya et } \\
\text { al., } 2014\end{array}$ \\
\hline $\begin{array}{l}\text { Boric acid and } \\
\text { ethylenediamine }\end{array}$ & $\begin{array}{l}\text { Iron (III) nitrate } \\
\text { nonahydrate }\end{array}$ & $60-200 \mathrm{~nm}$ & $\begin{array}{l}\text { Wu et al., } \\
2017\end{array}$ \\
\hline $\begin{array}{l}\text { Boron powder, citric acid, } \\
\text { polyethylene glycol } \\
\text { (PEG; molecular weight: } \\
1000 \text { ) }\end{array}$ & $\begin{array}{l}\text { Cobalt (II) nitrate } \\
\text { hexahydrate }\end{array}$ & $20-80 \mathrm{~nm}$ & $\begin{array}{l}\text { Wang et } \\
\text { al., } 2018\end{array}$ \\
\hline Boric oxide and urea & $\begin{array}{l}\text { Copper sulphate penta- } \\
\text { hydrate }\end{array}$ & $8-45 \mathrm{~nm}$ & $\begin{array}{l}\text { Kumar et } \\
\text { al., } 2018\end{array}$ \\
\hline $\begin{array}{l}\text { Boron oxide and } \\
\text { magnesium oxide }\end{array}$ & Magnesium vapor & About $70 \mathrm{~nm}$ & $\begin{array}{l}\text { Tang et } \\
\text { al., } 2002\end{array}$ \\
\hline Boron powder & $\begin{array}{l}\text { Magnesium oxide and } \\
\text { iron oxide }\end{array}$ & $\begin{array}{l}\text { At the growth temperature from } 1200 \text { to } 1300 \circ \mathrm{C} \\
\text { the average diameter from } \sim 30 \text { to } \sim 60 \mathrm{~nm} \text { was } \\
\text { obtained. However, at } 1400{ }^{\circ} \mathrm{C} \text { average diameters } \\
\text { as } \sim 20 \text { and } \sim 100 \mathrm{~nm} \text { were obtained. }\end{array}$ & $\begin{array}{l}\text { Pakdel et } \\
\text { al., } 2012\end{array}$ \\
\hline Boron Powder & $\begin{array}{l}\text { Ferric chloride } \\
\text { hexahydrate }\end{array}$ & $20-100 \mathrm{~nm}$ & $\begin{array}{l}\text { Pan et al., } \\
2014\end{array}$ \\
\hline Boric acid and melamine & Without catalyst & About $500 \mathrm{~nm}$ & $\begin{array}{l}\text { Ansaloni } \\
\text { et al., } \\
2013\end{array}$ \\
\hline $\begin{array}{l}\text { Amorphous boron } \\
\text { powder }\end{array}$ & $\begin{array}{l}\text { Iron (III) oxide and } \\
\text { magnesium oxide }\end{array}$ & $1-2 \mu \mathrm{m}$ & $\begin{array}{l}\text { Ahmad et } \\
\text { al., } 2015\end{array}$ \\
\hline Boron powder & $\begin{array}{l}\text { Magnesium oxide and } \\
\text { iron oxide }\end{array}$ & $10-100 \mathrm{~nm}$ & $\begin{array}{l}\text { Lee et al., } \\
2008\end{array}$ \\
\hline Boron trioxide and urea & $\begin{array}{l}\text { Iron (III) oxide } \\
\text { nanoparticles }\end{array}$ & About $50 \mathrm{~nm}$ & This study \\
\hline
\end{tabular}

\section{Conclusion}

As a result, BNNTs, which gathered interest with their unique properties and many application areas, were obtained with high yield and purity under optimum conditions by using a new method and precursor materials. Moreover, the structures and morphologies of BNNTs obtained using different characterization techniques were well illuminated. In addition, high purity BNNTs can be used in biological applications in the future. 


\section{References}

Ahmad, P., Khandaker, M. U., Amin, Y. M. and Khan, Z. R. (2015). Synthesis of boron nitride microtubes and formation of boron nitride nanosheets. Materials and Manufacturing Processes, $\quad 30, \quad 184-188$. https://doi.org/10.1080/10426914.2014.952041.

Ansaloni, L. M. S. and Sousa, E. M. B. (2013). Boron nitride nanostructured: synthesis, characterization and potential use in cosmetics. Materials Sciences and Applications, 4, 22-28. https://doi.org/10.4236/msa.2013.41004.

Arenal, R., Ferrari, A. C., Reich, S., Wirtz, L., Mevellec, J. Y., Lefrant, S., Rubio, A. and Loiseau, A. (2006). Raman spectroscopy of single-wall boron nitride nanotubes. Nano Letters, 6(8), 1812-1816. https://doi.org/10.1021/n10602544.

Bai, X. D., Golberg, D., Bando, Y., Zhi, C., Tang, C., Mitome, M. and Kurashima, K. (2007). Deformation-driven electrical transport of individual boron nitride nanotubes. Nano Letters, $7(3)$, 632-637. https://doi.org/10.1021/n10625401.

Berber, S., Kwon, Y. K. and Tomanek, D. (2000). Unusually high thermal conductivity of carbon nanotubes. Physical Review Letters, 84(29), 4613-4616.

https://doi.org/10.1103/PhysRevLett.84.4613.

Cao, F., Ren, W., Ji, Y. M. and Zhao, C. (2009). The structural and electronic properties of aminefunctionalized boron nitride nanotubes via ammonia plasmas: a density functional theory study. Nanotechnology, 20(19), 145703. https://doi.org/10.1088/09574484/20/14/145703.

Chang, C. W. A., Fennimore, M., Afanasiev, A., Okawa, D., Ikuno, T., Garcia, H., Li, D., Majumdar, A. and Zettl, A. (2006). Isotope efect on the thermal conductivity of boron nitride nanotubes. Physical Review Letters, 97(8), 085901. https://doi.org/10.1103/PhysRevLett.97.085901.

Chang, C. W., Han, W. Q. and Zettl, A. (2005). Termal conductivity of B-C-N and BN nanotubes. Journal of Vacuum Science \& Technology B, 23(5), 1-3. https://doi.org/10.1116/1.2008266.

Chen, X., Wu, P., Rousseas, M., Okawa, D., Gartner, Z., Zettl, A. and Bertozzi, C. R. (2009). Boron nitride nanotubes are noncytotoxic and can be functionalized for interaction with proteins and cells. Journal of the American Chemical Society, 131(3), 890-891. https://doi.org/10.1021/ja807334b.

Ciofani, G. (2010). Potential applications of boron nitride nanotubes as drug delivery systems.
Expert Opinion on Drug Delivery, 7(8), 889-893. https://doi.org/10.1517/17425247.2010.499897.

Ciofani, G., Raffa, V., Menciassi, A. and Cuschieri, A. (2009). Boron nitride nanotubes: an innovative tool for nanomedicine. Nano Today, 4(1), 8-10. https://doi.org/10.1016/j.nantod.2008.09.001

Eti Maden for life. (2021). Boron in the world.

Ferreira, T. H., Silva, P. R. O. and Santos, R. G. (2011). A novel synthesis route to produce boron nitride nanotubes for bioapplications. Journal of Biomaterials and Nanobiotechnology, 2, 426434. https://doi.org/10.4236/jbnb.2011.24052.

Fu, L., Wang, T., Yu, J., Dai, W., Sun, H., Liu, Z., Sun, R., Jiang, N., Yu, A. and Lin, C. T. (2017). An ultrathin high-performance heat spreader fabricated with hydroxylated boron nitride nanosheets. 2D Materials, 4(2), 025047. https://doi.org/10.1088/2053-1583/aa636e.

Gao, Z., Zhi, C., Bando, Y., Golberg, D. and Serizawa, T. (2011). Noncovalent functionalization of disentangled boron nitride nanotubes with favin mononucleotides for strong and stable visiblelight emission in aqueous solution. ACS Applied Materials \& Interfaces, 3(3), 627-632. https://doi.org/10.1021/am1010699.

Gao, Z., Zhi, C., Bando, Y., Golberg, D., Komiyama, M. and Serizawa, T. (2012). Efficient disentanglement of boron nitride nanotubes using water-soluble polysaccharides for protein immobilization. RSC Advances, 2(15), 62006208. https://doi.org/10.1039/C2RA20765F.

Iijima, S. (1991). Helical microtubules of graphitic carbon, Nature, 354(6348), 56-58. https://doi.org/10.1038/354056a0.

Kalay, S., Yilmaz, Z. and Çulha, M. (2013). Synthesis of boron nitride nanotubes from unprocessed colemanite. Beilstein Journal of Nanotechnology, $\quad 4, \quad 843-851$. https://doi.org/10.3762/bjnano.4.95.

Kumar, V., Lahiri, D. and Lahiri, I. (2018). Synthesis of boron nitride nanotubes and boron nitride nanoflakes with potential application in bioimaging. Materials Today: Proceedings, 5(8), 16756-16762.

https://doi.org/10.1016/j.matpr.2018.06.037.

Lauret, J. S., Arenal, R., Ducastelle, F., Loiseau, A., Cau, M., Tretout, B. A., Rosencher, E. and Capes, L. G. (2005). Optical transitions in singlewall boron nitride nanotubes. Physical Review Letters, $\quad 94(3), \quad 037405$. https://doi.org/10.1103/PhysRevLett.94.037405.

Lee, C. H., Wang, J., Kayatsha, V. K., Huang, J. Y. and Yap, Y. K. (2008). Effective growth of boron 
nitride nanotubes by thermal chemical vapor deposition. Nanotechnology, 19, 455605. https://doi.org/10.1088/0957-

4484/19/45/455605.

Lee, C. H., Xie, M., Kayastha, V., Wang, J. and Yap, Y. K. (2010). Patterned growth of boron nitride nanotubes by catalytic chemical vapor deposition. Chemistry of Materials, 22(5), 17821787. https://doi.org/10.1021/cm903287u.

Nithya, J. S. M. and Pandurangan, A. (2014). Efficient mixed metal oxide routed synthesis of boron nitride nanotubes. RSC Advances, 4, 26697. https://doi.org/10.1039/c4ra01204f.

Pakdel, A., Zhi, C., Bando, Y., Nakayama, T. and Golberg, D. (2012). A comprehensive analysis of the CVD growth of boron nitride nanotubes. Nanotechnology, 23, 215601. https://doi.org/10.1088/0957$4484 / 23 / 21 / 215601$.

Pan, A. and Chen, Y. (2014). Large-scale fabrication of boron nitride nanotubes with high purity via solid-state reaction Method. Nanoscale Research Letters, 9, 555. https://doi.org/10.1186/1556276X-9-555.

Roy, A. K., Park, B., Lee, K. S., Park, S. Y. and In, I. (2014). Boron nitride nanosheets decorated with silver nanoparticles through mussel-inspired chemistry of dopamine. Nanotechnology, 25(44), 445603. $4484 / 25 / 44 / 445603$

Salvetti, A., Rossi, L., Iacopetti, P., Li, X., Nitti, S., Pellegrino, T., Mattoli, V., Golberg, D. and Ciofani, G. (2015). In vivo biocompatibility of boron nitride nanotubes: effects on stem cell biology and tissue regeneration in planarians.
Nanomedicine (London), 10(12), 1911-1922. https://doi.org/10.2217/nnm.15.46.

Şen, Ö., Çobandede, Z., Emanet, M., Bayrak, Ö.F. and Çulha, M. (2017). Boron nitride nanotubes for gene silencing. Biochimica et Biophysica ActaGeneral Subjects, 1861(9), 2391-2397. https://doi.org/10.1016/j.bbagen.2017.05.026.

Tang, C., Bando, Y., Sato, T. and Kurashima, K. (2002). A novel precursor for synthesis of pure boron nitride nanotubes. Chemical Communications, 12 , 1290-1291. https://doi.org/10.1039/B202177C

Wang, H., Wang, W., Wang, H., Zhang, F., Li, Y. and $\mathrm{Fu}$, Z. (2018). Synthesis of boron nitride nanotubes by combining citrate nitrate combustion reaction and catalytic chemical vapor deposition. Ceramics International, 44(12), 13959- 13966. https://doi.org/10.1016/j.ceramint.2018.04.245.

Wu, J., Chen, H., Zhao, L., He, X., Fang, W., Li, W. and $\mathrm{Du}$, X. (2017). Synthesis of boron nitride nanotubes by catalytic pyrolysis of organiinorganic hybrid precursor. Ceramics International, 43(6), 5145-5149. https://doi.org/10.1016/j.ceramint.2017.01.029.

Xu, S., Fan, Y., Luo, J., Zhang, L., Wang, W., Yao, B. and An, L. (2007). Phonon characteristics and photoluminescence of bamboo structured silicon-doped boron nitride multiwall nanotubes. Applied Physics Letters, 90, 013115. https://doi.org/10.1063/1.2429904.

Zhi, C., Bando, Y., Wang, W., Tang, C., Kuwahara, H. and Golberg, D. (2007). DNA-mediated assembly of boron nitride nanotubes. Chemistry: An Asian Journal, 2(12), 1581-1585. https://doi.org/10.1002/asia.2007002. 